The psychological dimension of transformation in teacher learning

\title{
The psychological dimension of transformation in teacher learning
}

Professor Effie Maclellan,

School of Education,

Faculty of Humanities, Arts and Social Sciences,

University of Strathclyde,

Glasgow,

G13 1PP

E-mail: e.maclellan@strath.ac.uk

Telephone: 01419503355

Effie Maclellan is Research Professor of Education 


\title{
The psychological dimension of transformation in teacher learning
}

\begin{abstract}
Against a background which recognises pedagogical content knowledge as the distinctive element of teacher competence/expertise, this theoretical essay argues for its central construct - that of transformation - to be understood by teachers and teacher-educators in psychological terms (as was originally proposed by Dewey). Transformation requires teachers to fashion disciplinary knowledge such that it is accessible to the learner. It is argued that for transformation to happen, teacher thinking must include a sophisticated grasp of cognition and metacognition if teachers are to be characterised as competent, let alone expert. This article is written within a context of considerable social and academic scrutiny in the United Kingdom of the form and content of professional teacher preparation and development. In recent years the contribution of psychological knowledge to teacher-education has been filtered through procedural lenses of how best to 'manage classrooms', 'assess learning', 'build confidence' or whatever without a matched concern for psychological constructs through which such issues might be interpreted; thus leaving teachers vulnerable in their professional understandings of learning and its complexities. That society now requires high-level cognitive engagement amongst its participants places cognitive and metacognitive demands on teachers which can only be met if they themselves are conceptually equipped.
\end{abstract}

Keywords -learning, cognition, metacognition, pedagogical content knowledge, transformation, working memory,

\section{Introduction}

Given the evidence for the quality of teaching being a significant predictor of educational achievement, teacher-education provision is of considerable interest both in the UK and further afield. There is a view that it is unfit for purpose (Berry, 2010); playing out in debates around the preparation of teachers for school education (DfE, 2010; Donaldson, 2010; Hayes, 


\section{The psychological dimension of transformation in teacher learning}

2011; OECD, 2011) and the preparation of academics to teach in higher education (BenPeretz, Kleeman, Reichenberg, \& Shimoni, 2010; Boyd \& Harris, 2010; Hutchings, Huber, \& Ciccone, 2011; Ransome, 2011). These debates acknowledge that teaching is a task which requires professional preparation, and that professional educators have particular expertise. The general term given to the expertise of the teacher is pedagogical knowledge, and a distinctive part of this is pedagogical content knowledge, with which this article is concerned.

Almost 30 years ago the term, pedagogical content knowledge, was introduced into the educational lexicon at the American Educational Research Association's Presidential Address (Van Driel, Veal, \& Janssen, 2001). Within a political context which denigrated the value of teacher-education, Shulman $(1986,1987)$ argued that domain-knowledge content of itself was insufficient for effective teaching. Rather, he argued, what made teaching effective was the complex blend of content knowledge with pedagogical knowledge. The resulting construct, pedagogical content knowledge, is one of the most commonly invoked in the pedagogical literature (Segall, 2004) and continues to inform policy, education practice and research in teaching and teacher-education (Deng, 2007). With the passage of time it was recognised that the rapid onset of technological developments could not stand apart from pedagogical content knowledge (PCK) and so an elaborated construct of technological pedagogical content knowledge (TPCK or, more recently, TPACK) (Angeli \& Valanides, 2009; Koehler, Mishra, \& Yahya, 2007; Mishra \& Koehler, 2006) is also part of the pedagogical lexicon. There is no argument with the idea that content and pedagogy are interrelated; with Shulman's original construct being extended to include technology knowledge (Koehler \& Mishra, 2009); or with the idea that such an interrelationship is a necessary platform from which to (learn to) teach (Angeli, 2005; Angeli \& Valanides, 2005; Niess, 2005). Rather this theoretical essay attempts to clarify what PCK's central concept of transformation means psychologically. 


\section{The psychological dimension of transformation in teacher learning}

The theoretical foundations of pedagogical content knowledge are characterised as underdeveloped (Bullough, 2001; Chen \& Ennis, 1995; Graham, 2011; Segall, 2004). One way in which such theorising is deficient is in its attention to teachers' psychological knowledge. Although psychology has a long-recognised connection with learning and teaching (Nummedal, Benson, \& Chew, 2002), its contribution to 'what works' in education practice is difficult to pin down because of the uncontrolled variables operating in most social settings (Graesser \& Hu, 2011). This essay argues for the importance of teachers' thinking to be more privileged in teacher preparation, and to be informed explicitly by the literature on cognition and metacognition, if teachers are to be positioned as competent let alone expert. This is not to recommend psychological knowledge as stand-alone course content, but as conceptual underpinnings supporting teaching to develop course structures, classroom activities, assessment practices, feedback mechanisms, and web-based activities. Through knowledge of psychological structures which are integral to complex/higher-order cognition (Mayer, 2002; Pintrich, 2002; Van Merriënboer \& Paas, 2003), teacher-educators can position novice and developing teachers (in either school or higher education) to have a psychological critical consciousness of learning and achievements, akin to the cultural critical consciousness advocated by some (Gay \& Kirkland, 2003; Howard, 2003).

\section{Method}

The argument is structured through synthesising the literature to go beyond the limits of isolated findings and identify shared knowledge, thereby allowing possible reflections on unchallenged assumptions and traditional practices (Biesta \& Burbules, 2003). The issue being explored is the extent to which pedagogical content knowledge (and the elaboration of technological pedagogical content knowledge) can be distinguished from efficacious 


\section{The psychological dimension of transformation in teacher learning}

pedagogical practices (Edwards, Higley, Zeruth, \& Murphy, 2007; John, 2002) and generic pedagogical knowledge (Atjonen, Korkeakoski, \& Mehtäläinen, 2011; Fernández-Balboa \& Stiehl, 1995; König, Blömeke, Paine, Schmidt, \& Hsieh, 2011). The obfuscation of the distinction is of concern lest learning be understood as a necessary consequence of teaching, rather than as having a complex causal role in the teaching endeavour (Begg, Davis, \& Bramald, 2003). This concern is rooted in the wider context of trivialising learning (Sharp, Bowker, \& Byrne, 2008) despite the educational, psychological and neuroscientific evidence which testifies to the complexity of learning.

The psychologically informed literature - harnessed because of its functional value in the design and implementation of meaningful education practice - on which the paper rests, privileges a cognitive view of learning. While it is recognised that there is a significant social dimension to learning, and that the classroom context for formal learning is socially mediated; the effects of collaboration and interaction cannot be appreciated without first recognising the role and robustness of individual understanding (Bransford \& Schwartz, 1999; Salomon \& Perkins, 1998; Schneider \& Stern, 2010). The article is organised as follows. First, the case is made for Transformation, at least in part, to be a psychological construct. Second, there is an outline of the essentially cognitive nature of Learning. There follows an account of the role of Cognition and Metacognition in Learning, pointing to their necessity in teacher-education.

\section{Transformation}

The teacher's capacity to transform his/her own understanding of disciplinary knowledge into the content of instruction for use in the classroom is the essence of Pedagogical Content Knowledge (Shulman, 1986, 1987). The purpose of transformation is to make subject-matter accessible to learners for their educational benefit. Explaining what transformation means - a 


\section{The psychological dimension of transformation in teacher learning}

point which Shulman recognised to be problematic - has generated differing accounts of the constituents of pedagogical content knowledge and their interrelationship(s). Having reviewed the literature, Bukova-Güzel (2010) developed a theoretical framework, a modified version of which is in Table 1, which lists 3 main categories of knowledge and various elements within each category .

Table 1

\begin{tabular}{|l|l|l|}
\hline $\begin{array}{l}\text { Knowledge of teaching } \\
\text { strategies and multiple } \\
\text { representations }\end{array}$ & Knowledge of learner & Knowledge of curriculum \\
\hline $\begin{array}{l}\text { Appropriate activities in } \\
\text { instruction }\end{array}$ & Learners' prior knowledge & $\begin{array}{l}\text { The elements of the curriculum } \\
\text { (conception, purposes, etc.) }\end{array}$ \\
\hline $\begin{array}{l}\text { Meaningful real life examples } \\
\text { and analogies in instruction }\end{array}$ & $\begin{array}{l}\text { Difficulties learners will face } \\
\text { during learning }\end{array}$ & $\begin{array}{l}\text { The varieties of pedagogical } \\
\text { resources in curricular areas and } \\
\text { how to use them }\end{array}$ \\
\hline $\begin{array}{l}\text { Different instructional strategies } \\
\text { in presentations (questioning, } \\
\text { telling, explaining) }\end{array}$ & Possible learner misconceptions & $\begin{array}{l}\text { Instruments to judge learning } \\
\text { and how to use them }\end{array}$ \\
\hline $\begin{array}{l}\text { Different representations } \\
\text { (graphics, tables, formulas, } \\
\text { concrete materials etc.) }\end{array}$ & Learner differences & $\begin{array}{l}\text { Horizontal and vertical } \\
\text { knowledge of a topic's 'place' in } \\
\text { the curriculum }\end{array}$ \\
\hline
\end{tabular}

adapted from Bukova-Güzel (2010)

The proposition that the teacher's expertise could be characterised as pedagogical content knowledge gave rise to many studies reporting how this expertise played out in curriculum delivery (Abd-El-Khalick, 2006; McDonough, Clarke, \& Clarke, 2002; Nilsson \& Van Driel, 2010; Van Driel, Verloop, \& De Vos, 1998) and in curriculum delivery mediated through technology (Chai, Ling Koh, Tsai, \& Lee Wee Tan, 2011; Koehler et al., 2007; Niess, 2005). There have even been attempts to 'measure' PCK (Johnston \& Ahtee, 2006; Rowan, Schilling, Ball, \& Miller, 2001) and TPACK (Archambault \& Crippen, 2009; Schmidt et al., 2009). While varying in detail, what all of these studies have in common is a characterisation of pedagogical content knowledge as descriptive reconstructions of how teachers present subject-matter and take account of learners' comments and previous knowledge. However, there are at least two problems with this characterisation. One is that what constitutes 


\section{The psychological dimension of transformation in teacher learning}

subject-matter is not reflected in such studies (Deng, 2007), implying that subject-matter is not contentious. Any suggestion that content to be taught is simply 'out there' and that it remains the same regardless of local conditions and context, misses the essential point which is that subject-matter is both different from, and an interpretation of, disciplinary knowledge (Doyle \& Carter, 2003; Rogers, 1997). Further such interpretation is not value-free, thus favouring particular cultural and epistemological perspectives over others (Apple, 2004). Disciplinary knowledge comprises the conceptual tools, the methods of operation and the validation criteria that knowledgeable people use when addressing problems from particular disciplinary perspectives. Subject-matter, on the other hand, is typically presented as a 'finished product' devoid of contestable intellectual content. While of course, debate about subject-matter is the proper preserve of curriculum theory (Deng \& Luke, 2008), the instantiation of subject-matter is mediated through teachers' and learners' psychological structures.

A second problem with characterising pedagogical content knowledge as descriptive accounts of teachers' behaviour is that these reflect outward appearance only, concealing underpinning thinking and reasoning (Cobb \& Bauersfeld, 1995; S. Wilson, Shulman, \& Richert, 1987). Indeed Shulman was clear that pedagogical content knowledge was not just multiple behavioural enactments of subject-matter 'teaching' but a way of thinking, more precisely labelled 'pedagogical reasoning', that occurs as teachers plan, adapt instruction to meet learners' needs, and reflect on teaching. This reasoning about what is academically, situationally and subjectively appropriate in the particular teaching situation is taking place at a symbolic level, without any necessary accompanying observable behaviour. Although such reasoning is not extensively documented, there are some powerful examples (Henningsen \& Stein, 1997; Hill et al., 2008), testifying to the importance of the teacher's cognitions. Teacher 


\section{The psychological dimension of transformation in teacher learning}

understanding of the cognitive and social affordances and constraints being experienced by learners is of critical importance in the teaching enterprise (Dewey, 1900). In other words teachers' accommodation of the range and scope of learners' experiences (Dewey, 1902) is one of the conduits through which subject-matter becomes accessible to learners. This accommodation was what Dewey (on whose idea Shulman's thesis developed) referred to as psychologising the subject-matter. While transformation has been argued to be a dominantly curricular concept (Deng \& Luke, 2008), Dewey (1902) argued that subject-matter could neither be imposed upon nor inserted into learners, without their cognitive mediations. Thus, for Dewey (Boydston, 1976-1983) it is the learner and "not the subject-matter which determines both quality and quantity of learning" (p. 276). Therefore, how particular learners construe (or misconstrue) the content to which they are exposed is a dynamic and central part of the relationship between teaching and learning; and is essentially psychological (Ausubel, 2000). This implies that teachers' own psychological knowledge is of profound importance because it is with this that they transform their understandings of disciplinary knowledge into effective instruction. In other words transformation operates at a psychological level, for which teachers need pertinent psychological knowledge which can support them in their own reasoning. What follows is an initial consideration of recent psychological literature on learning, cognition and metacognition.

\section{Learning as Understanding}

Learning is a construct whose meaning has changed with the passage of time (De Corte, 2010) but it is essentially the process of coming to understand (Goodyear, 2007) necessitating learner's awareness of the critical, or criterial, features of whatever it is that is to be learned (Marton, 2007). So, for example, understanding what a square is means discerning something very specific about the angles of a square (they are all right angles) about the sides of a 


\section{The psychological dimension of transformation in teacher learning}

square (the length of each side is the same) and about differences in squares (they can have different areas); but it also means knowing/seeing/understanding in what ways a square differs from other quadrilaterals and from triangles. Similarly, understanding democracy means appreciating some difficult but constituent ideas about voting, representation, equality and freedom. It also involves recognising different types of democracy (such as direct and representative) and possibly contrasting democracy with other forms of government such as autocracy, fascism or hereditary (as distinct from constitutional) monarchies. Understanding is logically impossible without first focusing on the criterial attributes of a concept and then comparing these with the criterial attributes of related concepts. The development of understanding represents the successful acquisition of new knowledge (Schneider \& Stern, 2010). For the avoidance of doubt, 'successful acquisition' is not about the quantity of knowledge but about its quality: about how it is structured by the individual such that he/she can use acquired information in a variety of contexts and at different times from those in which the information was actually acquired (Bransford, Brown, \& Cocking, 1999; Schraw, 2005). Having transferable knowledge means having information which answers 'how' and 'why' questions (as well as 'who', 'what', 'where' and 'when' questions) for which individuals require to organise information into personally meaningful structures. It is through personal organisation/structuring of information that learners have an understanding of it. Enabling learners to construct understanding is a prime function of teaching (Newton, 2012).

\section{Teaching as Triggering Cognition}

Learners' knowledge is important to the teacher. In enabling others to successfully acquire knowledge, the teacher is attempting to engage learners such that they trigger their own cognitive processes to work on information (Marton \& Pang, 2006; Marzano \& Kendall, 2007), with a view to developing intentional learning (Bereiter \& Scardamalia, 1989; Sinatra 


\section{The psychological dimension of transformation in teacher learning}

\& Pintrich, 2003). Intentional learning is purposeful, internally initiated cognitive activity in the service of knowledge and skill development, but it is not an automatic consequence of educational experiences: learners may address tasks in ways that economise on mental effort, thereby avoiding the additional effort through which they might become more expert. For example, the teacher might believe in the value of tasking students to construct summaries of their reading and so builds summarisation tasks into lesson designs. But the students, finding summarisation both demanding and time consuming and being unwilling to persevere with the task as intended, shortcut the task either by using computer software to condense the text or divvying up the task amongst a group of peers. So the students have, on the surface, fulfilled the tutor's expectations but have actually subverted the tutor's laudable actual intentions for their learning by avoiding the full and actual cognitive processing that was intended. Alternative explanations of motivation will differ in their accounts of why students engage with, or resist, pedagogical guidance. A psychoanalytic perspective (Bibby, 2011; Bion, 1961; Britzman, 2003) could provide a nuanced adjunct to the argument offered in this essay but space limitations preclude this.

Because research indicates that what learners learn cannot be separated from how they learn it, it is necessary for teachers to be as concerned about learners' cognitive processing as about coverage of content. Both what and how learners transfer what they have learned in one situation to a new situation are important, and problematic, questions confronting education (Goldstone \& Wilensky, 2008). Transfer is influenced by factors such as: the generalisability of the intended learning (principles and concepts versus facts); the sophistication of learner self-monitoring and self-explanations; the role of others; the nature and extent of feedback; and the extent to which self-regulation is required (Billing, 2007). As well as there being no common understanding of optimum balance between content and cognitive processing 


\section{The psychological dimension of transformation in teacher learning}

(Prøitz, 2010), cognitive processing implicates an array of intellectual skills, the full range of which may not be in pedagogical focus (Flores, Matkin, Burbach, Quinn, \& Harding, 2010). Transferable knowledge is not, therefore, a repository of facts and general principles but the active representation of ideas, theories, plans and designs that have varied uses, may be judged valuable or worthless, and can be modified and improved upon.

The dynamic nature of transferable knowledge means that we can influence environments. For example, behind every new car, vacuum cleaner or washing machine is a design which can be manifest in successively 'newer models'. In developing the physical product to make it 'greener', to increase servicing intervals, to debug recurring problems or otherwise improve it, particular aspects of the product's design will be revisited, tweaked and tested. Similarly plans will be devised (and revised) to gain local authority approval for house building, and maps will be re-drawn when the road layout changes. Such critiquing of knowledge invokes the use and development of psychological tools (language and gesture, reading and writing and social interactions) which allow us to make meaning, construct representations and be aware of self (Säljö 1995). Interpreting, critiquing and constructing knowledge is influenced by extant knowledge in long term memory, organised as chunks of information called

schemata. As schemata are successively elaborated into meaningful networks they become more complex, linking together arrays of connected pieces of knowledge which, for each individual, are unique configurations of words, pictures, numbers, charts and graphs (DiSessa, 2004). The central pedagogical issue therefore is the extent to which the task in hand stimulates learners to construct more refined, schemata since these schemata are the basis for understanding (Ohlsson, 1995) and necessary for future learning (Bransford \& Schwartz, 1999). 


\section{The psychological dimension of transformation in teacher learning}

\section{Cognition requires Memory}

Cognitive activity depends on the contents of long term memory and the functioning of working memory. Working memory processes information that is already stored in, or is about to be stored in, long term memory. When schemata are brought into working memory, any one schema represents only a single element of information though, of itself, may be very complicated. This repeated and successive chunking of, and with time and practice automation of, information into increasingly more sophisticated schemata constitutes learning. So understanding comes about because some situation or stimulus causes us to build a bigger and/or better network (schema) from existing information we already hold in long term memory or because we connect a new piece of information to information that we already hold. Either way, the new connection made lets us see some aspect of the world differently, and thereby institute our own conceptual change. But working memory has two critically important characteristics. One is its limited storage and processing capacities for novel information. It can hold about seven items but can probably only process - as oppose to hold - two or three items of new information simultaneously. The other characteristic of working memory is its instability. There is a very short duration of time (a matter of seconds) before the information is lost, although the individual may activate other cognitive resources to maintain the information in immediate awareness.

\section{Significance of limited processing capacity}

Limited processing capacity may cause learners to experience difficulties. It might be judged, for example, that the content to be learned is too difficult because learners have to process too many elements (concepts or procedure) simultaneously (Sweller \& Chandler, 1994). Having to think of several things at once is particularly problematic when each and every element is new knowledge (what is technically known as intrinsic cognitive load). One possible solution 


\section{The psychological dimension of transformation in teacher learning}

is to consider simpler learning tasks which omit some of the interacting elements. However, insufficient segmentation means that learners will continue to be overwhelmed by task difficulty; possibly resorting to superficial processing, while over-segmentation may distract learners through redundant detail at the expense of constructing more refined schemata (Nadolski, Kirschner, \& Van Merriënboer, 2005). Further, simpler tasks may be appropriate interim learning points, but may not include essential interacting elements; possibly compromising learner understanding. Teachers therefore have to judge how and when they reintroduce essentially complex interacting elements (Paas, Renkl, \& Sweller, 2003). One possible and useful scaffold is to provide problem-solving tasks in which some of the subtasks have already been completed (Koedinger \& Aleven, 2007; Van Merriënboer, Kirschner, \& Kester, 2003).

Working memory's limitations might also suggest increasing instructional guidance, which sounds appealing given that applications such as discovery learning, problem-based learning and experiential learning are insufficiently structured to support the cognitive processing necessary for learning (P. Kirschner, Sweller, \& Clark, 2006). But unqualified use of instructional guidance can be unhelpful. What is essential instruction for novice learners (to avoid overload) may not be useful to more experienced learners because they have a larger number of schemata already in long-term memory which may actually interfere with processing (Kalyuga, 2007). Useful alternatives to traditional teacher explanation include generic guidance on a just-in-time basis (Hulshof \& De Jong, 2006); graduated degrees of practice in tasks rather than procedural direction (Brunstein, Betts, \& Anderson, 2009); and providing worked examples for learners to analyse (Schwonke et al., 2009). The tailoring of instruction to adapt to changing levels of domain knowledge is clearly challenging, not only because learners bring an array of characteristics to any learning task but also because 


\section{The psychological dimension of transformation in teacher learning}

guidance (more practice, worked examples, hints and tips, and materials in different modalities) can be judged effective only if it triggers rather than displaces learners' own cognitive engagement (De Jong, 2010). Teachers need to be sensitive to issues such as learners' performance not improving with effort; tasks experienced as impossibly difficult regardless of motivation; and increased time-on-task not producing better learning (Corbalan, Kester, \& Van Merriënboer, 2008; Martin, 2008; Nadolski et al., 2005). The evidence for working memory's limitations is robust so educational practice must optimise cognitive load. This is not effected through simplistic behavioural changes to practice but through an understanding of working memory's limitations. To avoid ineffective instruction therefore, teachers need to stimulate processes that foster learning, attenuate processes that interfere with learning, and calibrate task difficulty with prior knowledge.

\section{Teaching as Triggering Metacognition}

For all that cognitive variables are hugely important in learning (Schneider \& Stern, 2010), most behaviour is influenced by social and contextual factors so what has hitherto been measured as 'purely cognitive' is also influenced by learners' beliefs about the task to be done; by the social environment(s) in which tasks takes place; and by perceptions of selves (and others), of tasks and of the environment (Schoenfeld, 1983). Thus learners need to be aware of their thinking processes and the factors that may be interacting with their thinking processes; and be able control their goals, behavioural tendencies, and attention (Krätzig \& Arbuthnott, 2009; Marzano \& Kendall, 2007). This awareness and control is known as metacognition: a multifaceted phenomenon - inextricably linked into human psychological functioning - comprising:

- knowledge about our own cognition (ideas, beliefs, facts, theories, strategies to think and remember, means of establishing the validity of knowledge) 


\section{The psychological dimension of transformation in teacher learning}

- awareness of our experiences in carrying out tasks (feelings of familiarity, difficulty, confidence, estimates of effort-expenditure, of time, of solution-correctness, implicit feedback about one's knowledge)

- skills we deliberately use to plan, monitor and regulate our cognition (Efklides, 2006, 2008).

Metacognition is a predictor of learning (Veenman, Van Hout-Wolters, \& Afflerbach, 2006; Veenman, Wilhelm, \& Beishuizen, 2004). For example, metacognition facilitates the development of critical thinking skills (Ku \& Ho, 2010; Magno, 2010) because the need to make inferences, deductions or interpretations (all constituents of critical thinking) necessitates that learners 'stand apart' from their own domain-knowledge and assumptions and how they use these to regulate their cognition. Metacognition is implicated in all levels of literacy development (Diakidoy, Mouskounti, \& Ioannides, 2011; Klein \& Rose, 2010; N. Wilson \& Smetana, 2011) because our participation in a Literate Society requires that we understand what is happening now, and contribute to what might happen in the future in respect of laws, procedure, policies, missions, contracts, timetables, plans, lists, timetables, and records. This participation depends on literacy through which we share meaning, agree interpretations, and elaborate points of view. Finally, metacognition is implicated in mathematical development as learners become aware that their fragmented knowledge is a necessary constituent of further learning (Furinghetti \& Morselli, 2009; Malmivuori, 2006; Ryan \& Williams, 2007); and in self-assessment, the purpose of which is to increase learner autonomy through self-monitoring and self-regulation (Ibabe \& Jauregizar, 2010).

Metacognition is not, however, some guaranteed self-instructional skill that is learned once and for all: it is metacognition's strong knowledge basis that enables persons to monitor and regulate their competence and performance. There are reasons to believe that metacognitive 


\section{The psychological dimension of transformation in teacher learning}

consciousness has to be nurtured: knowledge construction is necessarily time-consuming and effortful; a tendency to preserve extant conceptual knowledge unless the necessity of its revision is compellingly obvious; and lack of awareness as to how to think may reinforce strategic learners to be satisfied with the procedural knowledge that allows immediate task resolution (Kuhn, 2009; Kuhn \& Udell, 2007; Magno, 2010). So both domain-specific knowledge (relevant concepts and theories; intrinsic conceptual issues in a domain; what is relevant/irrelevant knowledge in a domain) and skills (generating/sequencing a workable set of problem-solving steps; determining benchmark by which performance can be judged) are necessary for metacognition to be effective (Veenman et al., 2006).

Metacognition allows us to be aware not only of our own thinking, but also of others' (Efklides, 2008; Iiskala, Vauras, Lehtinen, \& Salonen, 2011; Salonen, Vauras, \& Efklides, 2005). Through appreciating someone else's knowledge we can engage in social interactions (King, 1998; Zembylas, 2007). Importantly in educational settings the teacher's model of how to interact with particular learners (in other words how teachers transforms disciplinary knowledge) derives from teachers' own metacognition (Kramarski \& Revach, 2009). At the same time, their management of the learning environment requires teachers to configure particular tasks, particular learners, particular materials and media to enable all learners to actively contribute to the attainment of mutual learning goals, to share effort to reach these goals together, and to learn from this combined effort (Janssen, Kirschner, Erkens, Kirschner, \& Paas, 2010; F. Kirschner, Paas, \& Kirschner, 2009)., Metacognition is thus a reflexive activity: allowing teachers to contemplate the thinking and reasoning of learners and, at the same time, it is the very mechanism through which teachers' own meaning-making and decision-making becomes apparent to them. Not surprisingly then, those teachers whose metacognitions are keenly honed demonstrate more teaching practices that promote learners' 


\section{The psychological dimension of transformation in teacher learning}

understanding. They are also superior in supporting learners' own regulation of learning (Kramarski \& Revach, 2009) through tweaking their engagements with learners (Postholm, 2010, 2011; N. Wilson \& Bai, 2010). There is, however, some urgency to developing more refined understandings of metacognition amongst teachers (Depaepe, De Corte, \& Verschaffel, 2010; Desoete, 2007; Veenman et al., 2006; Zohar \& Ben David, 2008).

\section{Bringing together transformation, learning, cognition and metacognition}

A distinctive part of teacher expertise is to enable learners to make sense of curriculum content. This necessitates that two criteria are met (Ausubel, 2000). One is that the material to be learned has some internal integrity: it should have the potential to relate to some aspect(s) of human experience and not be random or arbitrary gobbets of information such as telephone numbers, scrambled sentences or nonsense syllables which can only be related to anyone's cognitive structure on a verbatim basis. The issue of content integrity has been alluded to earlier but is not substantive in this article. A second criterion is that whether or not the learner constructs meaning from/with subject-matter depends on the individual learner's cognitive structures. Construction of meaning is not a general or guaranteed consequence of exposure to inherently meaningful content: it requires anchorage in each learner's prior knowledge and while the activation of prior knowledge is not straightforward (Gurlitt \& Renkl, 2010), it is the basis for and simultaneously interconnecting and integrating new elements of information (Kalyuga, 2009). To this extent learning is an individual activity (Schneider \& Stern, 2010).

However, the formal educational system is not and never has been one of solitary selfinstruction: sociocultural perspectives point to the inseparability of person-from-context (Lemke, 2001; Posner, Strike, Hewson, \& Gertzog, 1982) and psychoanalytic perspectives to 


\section{The psychological dimension of transformation in teacher learning}

the necessary but difficult relational balance of teacher-learner engagement (Bibby, 2011; Bion, 1961). Learning is not something that we can do completely on our own. Not only is the determination and development of curricular content the responsibility of pedagogically sophisticated persons, the world-wide recognition of the centrality of social interaction points to the importance of the teacher's role in promoting learner collaboration (Webb et al., 2008). Cognition is thus an interactive activity of persons and situations with knowledge being situated in the activity, context and culture of its development and use (Brown, Collins, \& Duguid, 1989). The teacher's role in this more nuanced milieu is a sophisticated one: simply placing students in small groups offers no guarantees of learning. What is critical is the orchestration of situations such that learner use their cognitive and metacognitive resources to attenuate working memory limitations.

Firstly learners need to work actively to complete a single, unified task that represents the shared meaning, conclusions and effort of the group as a unit. Successful group task completion permits group members (Janssen et al., 2010) each to increase flexibility and transferability in their own knowledge and skills provided the task requires problem solution rather than unprocessed recall of stored information (F. Kirschner et al., 2009). The extent to which learners give and receive help, share knowledge, justify their ideas and build on peer contributions is mediated through the metacognitions of the participants who elaborate, question, explain, correct and reconcile relevant knowledge proffered by individual group members. These collaborative situations require individuals to explain their ideas and conceptions and through this externalisation of their cognitive processing, make visible to themselves and others their own understandings; thereby allowing the possibility of understandings being reorganised, modified or supplemented (Olivera \& Straus, 2004; Van den Bossche, Gijselaers, Segers, \& Kirschner, 2006). Transformation of subject-matter to 


\section{The psychological dimension of transformation in teacher learning}

enable learner accessibility may thus involve the agency of others to reduce cognitive load (Janssen et al., 2010) and/or to conceptualise problems, create shared understanding and produce new knowledge (Damşa, Kirschner, Andriessen, Erkens, \& Sins, 2010).

Secondly, group work requires regulative activity (such as setting goals, monitoring collaborative effort, and negotiating future courses of action) through which learners recognise and resolve contradictions between their own and others' perspectives. These process-related activities steer and organise the construction of corporate knowledge, through reflecting intentions to engage actively in the learning task, ensuring the co-ordination of different contributions, and furthering the beneficial effects of social interaction (Damşa et al., 2010; Hurme, Palonen, \& Järvela, 2006). Further such activity needs time; for constructive discussion and debate, and for the routinisation of regulative behaviour in the service of successfully acquiring new knowledge, (Brunstein et al., 2009; Ku \& Ho, 2010; Maggioni \& Parkinson, 2008; Magno, 2010; Peters \& Kitsantas, 2010; Schunk, 2008). The transparency of these interactions is necessary in order to surface a collective social consciousness, in which learners are valued and concerned for others' learning (Kotsopoulos, 2010). Not only do learners need to become aware of their own actions but also become aware that others are also aware of their actions.

What seems to be important is that teachers require learners to explain and elaborate their explanations regardless of response 'accuracy'. Teachers who push learners to describe their thinking, ask questions of clarification and make explicit the steps in learners' mental processes (even when answers and strategies are correct) are working with learners to refine their conceptions. Teacher guidance on how to resolve discrepant answers by listening to, and trying to understand, each other's explanations, and not accepting others' answers unless 


\section{The psychological dimension of transformation in teacher learning}

learners can explain why they were correct enacts the essential message that learning is about constructing meaning (Webb et al., 2008). On the other hand, teachers who do not press to understand a particular learner's misconceptions or prompt learners to explain themselves may unwittingly encourage learners not to engage in intentional learning (Vermunt \& Vermetten, 2004). Learners' responses are mediated through what they themselves understand by the idea of, and their role in, the learning process (Clark \& Schroth, 2010; Elen \& Lowyck, 1998). For this, learners' and teachers' cognitive and metacognitive resources matter.

\section{Final Thoughts}

The current press to improve teacher-education (whether for school or tertiary provision) unsurprisingly suggests that the focus should be on what happens in classrooms. This is a laudable direction of travel, given the wealth of research evidence which draws attention to useful pedagogical practices to consider in Education practice. In an attempt to keep teachers updated, practice guidelines and standards which distil salient findings are produced (Faubert, 2012; Pashler et al., 2007). Regardless of how rigorous or robust such outputs may be, they can offer no more than general principles; which must be interpreted so that their application is appropriately matched to different individual learners in contrasting classroom environments. It has been stressed throughout that what is important is the articulation of teachers' knowledge with learners' extant knowledge. For this to happen, teachers' transformations which depend on their own cognitions and metacognitions are very significant. Thus, all teacher-education provision needs to embrace these foundational concepts of learning, cognition and metacognition since it is only through teachers' and teacher-educators' own awareness of the complexity of their own learning that they can integrate educational theory with their own knowledge of what works in practice. Attention 


\section{The psychological dimension of transformation in teacher learning}

to these aspects of learning (and teaching) is in danger of getting lost if teacher-education

does not take a much more comprehensive account of the psychological literature.

\section{References}

Abd-El-Khalick, F. (2006). Preservice and experienced Biology teachers' global and subject specific subject matter structures: implications for conceptions of pedagogical content knowledge. Eurasia Journal of Mathematics, Science and Technology Education, 2(1).

Angeli, C. (2005). Transforming a teacher education method course through technology: effects on preservice teachers' technology competency. Computers \& Education, 45(4), 383-398.

Angeli, C., \& Valanides, N. (2005). Preservice elementary teachers as information and communication technology designers: an instructional systems design model based on an expanded view of pedagogical content knowledge. Journal of Computer Assisted Learning, 21(4), 292-302.

Angeli, C., \& Valanides, N. (2009). Epistemological and methodological issues for the conceptualization, development, and assessment of ICT-TPCK: advances in technological pedagogical content knowledge (TPCK). Computers \& Education, 52(1), 154-168.

Apple, M. (2004). What are the aims of education in the new America? the imperatives of the No Child Left Behind Act. Educational Policy 18(1), 12-44.

Archambault, L., \& Crippen, K. (2009). Examining TPACK among K-12 online distance educators in the United States Contemporary Issues in Technology and Teacher Education 9(1), 71-88.

Atjonen, P., Korkeakoski, E., \& Mehtäläinen, J. (2011). Key pedagogical principles and their major obstacles as perceived by comprehensive school teachers. Teachers and Teaching 17 (3 ), 273 $-288$.

Ausubel, D. (2000). The Acquisition and Retention of knowledge: a cognitive view. Dordrecht: Kluwer Academic Publisher.

Begg, A., Davis, B., \& Bramald, R. (2003). Obstacles to the dissemination of mathematics education research. In A. Bishop, M. Clements, C. Keitel, J. Kilpatrick \& F. Leung (Eds.), Second International Handbook of Mathematics Education (Vol. 2, pp. 593-634). Dordrecht: Kluwer Academic Publishers.

Ben-Peretz, M., Kleeman, S., Reichenberg, R., \& Shimoni, S. (2010). Educators of educators: their goals, perceptions and practices. Professional Development in Education, 36(1-2), 111-129.

Bereiter, C., \& Scardamalia, M. (1989). Intentional learning. In L. Resnick (Ed.), Knowing, Learning and Instruction (pp. 361-392). Hillsdale, New Jersey: Lawrence Erlbaum Associates.

Berry, B. (2010). Teacher Education for Tomorrow. Hillsborough: Center for Teaching Quality.

Bibby, T. (2011). Education - An 'Impossible Profession'? London: Routledge.

Biesta, G., \& Burbules, N. (2003). Pragmatism and Educational Research. Oxford: Rowman \& Littlefield Publishers.

Billing, D. (2007). Teaching for transfer of core/key skills in higher education: cognitive skills. Higher Education, 53 483-516.

Bion, W. (1961). Experiences in Groups. London: Tavistock Publications Ltd.

Boyd, P., \& Harris, K. (2010). Becoming a university lecturer in teacher education: expert school teachers reconstructing their pedagogy and identity. Professional Development in Education, 36(1-2), 9-24.

Boydston, J. (Ed.). (1976-1983). The Middle Works of John Dewey, 1899-1924 (Vol. 2). Carbondale: Southern Illinois University Press.

Bransford, J., Brown, A., \& Cocking, R. (1999). How people learn: mind, brain, experience, and school. Washington DC: National Academy Press.

Bransford, J., \& Schwartz, D. (1999). Rethinking Transfer: a simple proposal with multiple implications. Review of Research in Education, 24(1), 61-100. doi: 10.3102/0091732x024001061

Britzman, D. (2003). After-Education: Anna Freud, Melanie Klein, and psychoanalytic histories of learning. Albany State University of New York Press. 


\section{The psychological dimension of transformation in teacher learning}

Brown, J., Collins, A., \& Duguid, P. (1989). Situated cognition and the culture of learning. Educational Researcher, 18(1), 32-42.

Brunstein, A., Betts, S., \& Anderson, J. (2009). Practice enables successful learning under minimal guidance. Journal of Educational Psychology, 101(4), 790-802.

Bukova-Güzel, E. (2010). An investigation of pre-service mathematics teachers' pedagogical content knowledge, using solid objects. Scientific Research and Essays, 5(14), pp. 1872-1880,.

Bullough, R. (2001). Pedagogical content knowledge circa 1907 and 1987: a study in the history of an idea. Teaching and Teacher Education, 17(6), 655-666.

Chai, C., Ling Koh, J., Tsai, C., \& Lee Wee Tan, L. (2011). Modeling primary school pre-service teachers' Technological Pedagogical Content Knowledge (TPACK) for meaningful learning with information and communication technology (ICT). Computers \& Education, 57(1), 1184-1193.

Chen, A., \& Ennis, C. (1995). Content knowledge transformation: an examination of the relationship between content knowledge and curricula. Teaching and Teacher Education, 11(4), 389-401.

Clark, M., \& Schroth, C. (2010). Examining relationships between academic motivation and personality among college students. Learning and Individual Differences, 20, 19-24.

Cobb, P., \& Bauersfeld, H. (Eds.). (1995). The Emergence of Mathematical Meaning : Interaction in Classroom Cultures Hillsdale, N.J.: L. Erlbaum Associates.

Corbalan, G., Kester, L., \& Van Merriënboer, J. (2008). Selecting learning tasks: effects of adaptation and shared control on learning efficiency and task involvement. Contemporary Educational Psychology, 33(4), 733-756.

Damşa, C., Kirschner, P., Andriessen, J., Erkens, G., \& Sins, P. (2010). Shared epistemic agency: an empirical study of an emergent construct. Journal of the Learning Sciences, 19(2), 143 - 186.

De Corte, E. (2010). Historical developments in the understanding of learning. In H. Dumont, D. Istance \& F. Benavides (Eds.), The Nature of Learning: Using Research to Inspire Practice (pp. 35-67). Paris: OECD Publishing.

De Jong, T. (2010). Cognitive load theory, educational research, and instructional design: some food for thought. Instructional Science, 38, 105-134.

Deng, Z. (2007). Transforming the subject matter: examining the intellectual roots of Pedagogical Content Knowledge. Curriculum Inquiry, 37(3), 279-295.

Deng, Z., \& Luke, A. (2008). Subject matter: defining and theorizing school subjects. In F. Connelly, H. M. \& J. Phillion (Eds.), The Sage Handbook of Curriculum and Instruction (pp. 66-87). London, UK: Sage Publications.

Depaepe, F., De Corte, E., \& Verschaffel, L. (2010). Teachers' metacognitive and heuristic approaches to word problem solving: analysis and impact on students' beliefs and performance. Zentralblatt für Didaktik der Mathematik (ZDM), 42(2), 205-218.

Desoete, A. (2007). Evaluating and improving the mathematics teaching-learning process through metacognition. Electronic Journal of Research in Educational Psychology, 5(3), 705-730.

Dewey, J. (1900). Psychology and social practice. Psychological Review, 7(2), 105-124.

Dewey, J. (1902). The Child and the Curriculum. Chicago: The University of Chicago Press.

DfE. (2010). The Case for Change. (DFE-00564-2010). London: Stationery Office Retrieved from http://www.education.gov.uk/publications//eOrderingDownload/DFE-00564-2010.pdf.

Diakidoy, I., Mouskounti, T., \& Ioannides, C. (2011). Comprehension and learning from refutation and expository texts. Reading Research Quarterly, 46(1), 22-38.

DiSessa, A. A. (2004). Metarepresentation: native competence and targets for instruction. Cognition and Instruction, 22(3), 293-331.

Donaldson, G. (2010). Teaching Scotland's Future - Report of a review of Teacher Education in Scotland. Edinburgh: The Scottish Government.

Doyle, W., \& Carter, K. (2003). Narrative and learning to teach: implications for teacher-education curriculum. Journal of Curriculum Studies, 35(2), 129-137.

Edwards, M., Higley, K., Zeruth, J., \& Murphy, P. (2007). Pedagogical practices: examining preservice teachers' perceptions of their abilities. Instructional Science, 35(5), 443-465.

Efklides, A. (2006). Metacognition and affect: what can metacognitive experiences tell us about the learning process? Educational Research Review, 1(1), 3-14. 


\section{The psychological dimension of transformation in teacher learning}

Efklides, A. (2008). Metacognition defining its facets and levels of functioning in relation to selfregulation and co-regulation. European Psychologist 13 277-228.

Elen, J., \& Lowyck, J. (1998). Students' views on the efficiency of instruction: an exploratory survey of the instructional metacognitive knowledge of university freshmen. Higher Education, $36(2), 231-252$.

Faubert, B. (2012). A Literature Review of School Practices to Overcome School Failure. Paris: OECD.

Fernández-Balboa, J., \& Stiehl, J. (1995). The generic nature of pedagogical content knowledge among college professors. Teaching and Teacher Education, 11(3), 293-306.

Flores, K., Matkin, G., Burbach, M., Quinn, C., \& Harding, H. (2010). Deficient Critical Thinking Skills among College Graduates: Implications for leadership. Educational Philosophy and Theory, no-no.

Furinghetti, F., \& Morselli, F. (2009). Every unsuccessful problem solver is unsuccessful in his or her own way: affective and cognitive factors in proving. Educational Studies in Mathematics, 70(1), 71-90.

Gay, G., \& Kirkland, K. (2003). Developing cultural critical consciousness and self-reflection in preservice teacher education. Theory into Practice, 42(3), 181-187.

Goldstone, R., \& Wilensky, U. (2008). Promoting transfer by grounding complex systems principles. Journal of the Learning Sciences, 17 (4), 465-516.

Goodyear, P. (2007). Discussion, collaborative knowledge work and epistemic fluency. British Journal of Educational Studies, 55(4), 351-368.

Graesser, A., \& Hu, X. (2011). Commentary on causal prescriptive statements. Educational Psychology Review, 23(2), 279-285.

Graham, C. (2011). Theoretical considerations for understanding technological pedagogical content knowledge (TPACK). Computers \& Education, 57(3), 1953-1960.

Gurlitt, J., \& Renkl, A. (2010). Prior knowledge activation: how different concept mapping tasks lead to substantial differences in cognitive processes, learning outcomes, and perceived selfefficacy. Instructional Science, 38, 417-443.

Hayes, D. (2011). In Defence of Teacher Education. Worcester: Standing Council for the Education and Training of Teachers (SCETT).

Henningsen, M., \& Stein, M. (1997). Mathematical tasks and student cognition: classroom-based factors that support and inhibit high-level mathematical thinking and reasoning. Journal for Research in Mathematics Education, 28(5), 524-549.

Hill, H., Blunk, M., Charalambous, C., Lewis, J., Phelps, G., Sleep, L., \& Ball, D. (2008). Mathematical knowledge for teaching and the mathematical quality of instruction: an exploratory study. Cognition and Instruction, 26, 430-511.

Howard, T. (2003). Culturally relevant pedagogy: ingredients for critical teacher reflection. Theory into Practice, 42(3), 195-202.

Hulshof, C., \& De Jong, T. (2006). Using just-in-time information to support scientific discovery learning about geometrical optics in a computer-based simulation Interactive Learning Environments 14 (1), 79-94.

Hurme, T., Palonen, T., \& Järvela, S. (2006). Metacognition in joint discussions: an analysis of the patterns of interaction and the metacognitive content of the networked discussions in mathematics. Metacognition and Learning, 1, 181-200.

Hutchings, P., Huber, M., \& Ciccone, A. (2011). Getting there: an integrative vision of the scholarship of teaching and learning International Journal for the Scholarship of Teaching and Learning, 5(1), 1-14.

Ibabe, I., \& Jauregizar, J. (2010). Online self-assessment with feedback and metacognitive knowledge. Higher Education, 59(2), 243-258.

Iiskala, T., Vauras, M., Lehtinen, E., \& Salonen, P. (2011). Socially shared metacognition of dyads of pupils in collaborative mathematical problem-solving processes. Learning and Instruction, 21(3), 379-393.

Janssen, J., Kirschner, F., Erkens, G., Kirschner, P., \& Paas, F. (2010). Making the black box of collaborative learning transparent: combining process-oriented and cognitive load approaches. Educational Psychology Review, 22, 139-154. 


\section{The psychological dimension of transformation in teacher learning}

John, P. (2002). The teacher educator's experience: case studies of practical professional knowledge. Teaching and Teacher Education, 18(3), 323-341.

Johnston, J., \& Ahtee, M. (2006). Comparing primary student teachers' attitudes, subject knowledge and pedagogical content knowledge needs in a physics activity. Teaching and Teacher Education, 22(4), 503-512.

Kalyuga, S. (2007). Expertise reversal effect and its implications for learner-tailored instruction. Educational Psychology Review, 19(4), 509-539.

Kalyuga, S. (2009). Knowledge elaboration: a cognitive load perspective Learning and Instruction, $19,402-410$.

King, A. (1998). Transactive peer tutoring: distributing cognition and metacognition. Educational Psychology Review, 10(1), 57-74.

Kirschner, F., Paas, F., \& Kirschner, P. (2009). Individual and group-based learning from complex cognitive tasks: effects on retention and transfer efficiency. Computers in Human Behavior, 25, 306-314.

Kirschner, P., Sweller, J., \& Clark, R. (2006). Why minimal guidance during instruction does not work: an analysis of the failure of constructivist, discovery, problem-based, experiential, and inquiry-based teaching. Educational Psychologist, 41(2), 75-86.

Klein, P., \& Rose, M. (2010). Teaching argument and explanation to prepare junior students for writing to learn. Reading Research Quarterly, 45(4), 433-461.

Koedinger, K., \& Aleven, V. (2007). Exploring the assistance dilemma in experiments with cognitive tutors. Educational Psychology Review, 19(3), 239-264.

Koehler, M., \& Mishra, P. (2009). What is technological pedagogical content knowledge? Contemporary Issues in Technology and Teacher Education, 9(1), 60-70.

Koehler, M., Mishra, P., \& Yahya, K. (2007). Tracing the development of teacher knowledge in a design seminar: integrating content, pedagogy and technology. Computers \& Education, 49(3), 740-762.

König, J., Blömeke, S., Paine, L., Schmidt, W., \& Hsieh, F. (2011). General pedagogical knowledge of future middle school teachers: on the complex ecology of Teacher Education in the United States, Germany, and Taiwan. Journal of Teacher Education, 62(2), 188-201.

Kotsopoulos, D. (2010). When collaborative is not collaborative: supporting student learning through self-surveillance. International Journal of Educational Research, 49(4-5), 129-140.

Kramarski, B., \& Revach, T. (2009). The challenge of self-regulated learning in mathematics teachers' professional training. Educational Studies in Mathematics, 72(3), 379-399.

Krätzig, G., \& Arbuthnott, K. (2009). Metacognitive learning: the effect of item-specific experience and age on metamemory calibration and planning. Metacognition and Learning, 4, 125-144.

$\mathrm{Ku}, \mathrm{K} .$, \& Ho, I. (2010). Metacognitive strategies that enhance critical thinking. Metacognition and Learning, 5, 251-267.

Kuhn, D. (2009). Do students need to be taught how to reason? Educational Research Review, 4, 1-6.

Kuhn, D., \& Udell, W. (2007). Coordinating own and other perspectives in argument. Thinking \& Reasoning, 13, 90-104.

Lemke, J. (2001). Articulating communities: sociocultural perspectives on science education. . Journal of Research in Science Teaching, 38(3), 296 - 316.

Maggioni, L., \& Parkinson, M. (2008). The role of teacher epistemic cognition, epistemic beliefs, and calibration in instruction. Educational Psychology Review, 20, 445-461.

Magno, C. (2010). The role of metacognitive skills in developing critical thinking. Metacognition and Learning, 5, 137-156.

Malmivuori, M. (2006). Affect and self-regulation. Educational Studies in Mathematics, 63(2), 149164.

Martin, A. (2008). How domain specific is motivation and engagement across school, sport, and music? a substantive-methodological synergy assessing young sportspeople and musicians. Contemporary Educational Psychology, 33(4), 785-813.

Marton, F. (2007). Towards a pedagogical theory of learning. British Journal of Educational Psychology, Monograph Series, II(4), 19-30.

Marton, F., \& Pang, M. (2006). On some necessary conditions of learning. Journal of the Learning Sciences, 15(2), 193 - 220. 


\section{The psychological dimension of transformation in teacher learning}

Marzano, R., \& Kendall, J. (2007). The New Taxonomy of Educational Objectives. Thousand Oaks, CA: Corwin Press.

Mayer, R. (2002). Rote versus Meaningful Learning. Theory into Practice, 41(4), 226-232.

McDonough, A., Clarke, B., \& Clarke, D. (2002). Understanding, assessing and developing children's mathematical thinking: the power of a one-to-one interview for preservice teachers in providing insights into appropriate pedagogical practices. International Journal of Educational Research, 37(2), 211-226.

Mishra, P., \& Koehler, M. (2006). Technological pedagogical content knowledge: a framework for teacher knowledge. Teacher's College Record, 108(6), 1017-1054.

Nadolski, R., Kirschner, P., \& Van Merriënboer, J. (2005). Optimizing the number of steps in learning tasks for complex skills. British Journal of Educational Psychology, 75, 223-237.

Newton, D. (2012). Teaching for Understanding (2nd ed.). Abingdon, Oxon: Routledge.

Niess, M. (2005). Preparing teachers to teach science and mathematics with technology: developing a technology pedagogical content knowledge. Teaching and Teacher Education, 21(5), 509523.

Nilsson, P., \& Van Driel, J. (2010). Teaching together and learning together - primary science student teachers' and their mentors' joint teaching and learning in the primary classroom. Teaching and Teacher Education, 26(6), 1309-1318.

Nummedal, S., Benson, J., \& Chew, S. (2002). Disciplinary styles in the scholarship of teaching and learning: a view from psychology. In M. Huber \& S. Morreale (Eds.), Disciplinary Styles in the Scholarship of Teaching and Learning: exploring common ground (pp. 163-179). Washington, DC: The American Association for Higher Education and the Carnegie Foundation for the Advancement of Teaching.

OECD. (2011). Building a High-Quality Teaching Profession: lessons from around the world. Paris: OECD Publishing.

Ohlsson, S. (1995). Learning to do and learning to understand. In P. Reimann \& H. Spada (Eds.), Learning in Humans and Machines (pp. 37- 62). Oxford: Pergamon.

Olivera, F., \& Straus, S. (2004). Group-to-individual transfer of learning: cognitive and and social factors. Small Group Research, 35, 440-465.

Paas, F., Renkl, A., \& Sweller, J. (2003). Cognitive load theory and instructional design: recent developments. Educational Psychologist, 38, 1-4.

Pashler, H., Bain, P., Bottge, B., Graesser, A., Koedinger, K., McDaniel, M., \& Metcalfe, J. (2007). Organizing Instruction and Study to Improve Student Learning. Washington, DC National Center for Education Research, Institute of Education Sciences, U.S. Department of Education.

Peters, E., \& Kitsantas, A. (2010). Self-regulation of student epistemic thinking in science: the role of metacognitive prompts. Educational Psychology, 30, 27-52.

Pintrich, P. (2002). The role of metacognitive knowledge in learning, teaching, and assessing. Theory into Practice, 4l(4), 219-225.

Posner, G., Strike, K., Hewson, P., \& Gertzog, W. (1982). Accommodation of a scientific conception: toward a theory of conceptual change. Science Education, 66(2), 211-227.

Postholm, M. (2010). Self-regulated pupils in teaching: teachers' experiences. Teachers and Teaching, 16(4), 491-505.

Postholm, M. (2011). Self-regulated learning in teaching: students' experiences. Teachers and Teaching, 17(3), 365-382.

Prøitz, T. (2010). Learning outcomes: What are they? Who defines them? When and where are they defined? Educational Assessment, Evaluation and Accountability, 22(2), 119-137.

Ransome, P. (2011). Qualitative pedagogy versus instrumentalism: the antinomies of higher education learning and teaching in the United Kingdom. Higher Education Quarterly, 65(2), 206-223.

Rogers, B. (1997). Informing the shape of the curriculum: new views of knowledge and its representation in schooling. Journal of Curriculum Studies, 29(6), 683-710.

Rowan, B., Schilling, S., Ball, D., \& Miller, R. (2001). Measuring Teachers' Pedagogical Content Knowledge in Surveys: An Exploratory Study. Institute of the American Institutes for Research. 


\section{The psychological dimension of transformation in teacher learning}

Ryan, J., \& Williams, J. (2007). Mathsmaps for diagnostic assessment with pre-service teachers: stories of mathematical knowledge. Research in Mathematics Education, 9(1), 95-109.

Salomon, G., \& Perkins, D. (1998). Individual and social aspects of learning. Review of Research in Education, 23, 1-24.

Salonen, P., Vauras, M., \& Efklides, A. (2005). Social interaction: what can it tell us about metacognition and co-regulation in learning? European Psychologist, 10(3), 199-208.

Schmidt, D., Baran, E., Thompson, A., Mishra, P., Koehler, M., \& Shin, T. (2009). Technological pedagogical content knowledge (TPACK): The development and validation of an assessment instrument for preservice teachers. Journal of Research on Technology in Education, 42(2), 123-149.

Schneider, M., \& Stern, E. (2010). The cognitive perspective on learning: ten cornerstone findings. In H. Dumont, D. Istance \& F. Benavides (Eds.), The Nature of Learning: Using Research to Inspire Practice (pp. 69-90). Paris: OECD Publishing.

Schoenfeld, A. (1983). Beyond the purely cognitive: belief systems, social cognitions, and metacognitions as driving forces in intellectual performance. Cognitive Science, 7(4), 329363.

Schraw, G. (2005). An Interview with K. Anders Ericsson. Educational Psychology Review, 17(4), $389-412$.

Schunk, D. (2008). Metacognition, self-regulation, and self-regulated learning: research recommendations. Educational Psychology Review, 20, 463-467.

Schwonke, R., Renkl, A., Krieg, C., Wittwer, J., Aleven, V., \& Salden, R. (2009). The workedexample effect: not an artefact of lousy control conditions. Computers in Human Behavior, 25(2), 258-266.

Segall, A. (2004). Revisiting pedagogical content knowledge: the pedagogy of content/the content of pedagogy. Teaching and Teacher Education, 20(5), 489-504.

Sharp, J., Bowker, R., \& Byrne, J. (2008). VAK or VAK-uous? Towards the trivialisation of learning and the death of scholarship. Research Papers in Education, 23(3), 293-314.

Shulman, L. (1986). Those who understand: knowledge growth in teaching Educational Researcher, 15, 4-14.

Shulman, L. (1987). Knowledge and teaching: foundations of the new reform. Harvard Educational Review, 57, 1-22.

Sinatra, G., \& Pintrich, P. (Eds.). (2003). Intentional Conceptual Change. Mahwah, N.J: Lawrence Erlbaum Associates.

Sweller, J., \& Chandler, P. (1994). Why some material is difficult to learn. Cognition and Instruction, 12(3), 185-233.

Van den Bossche, P., Gijselaers, W., Segers, M., \& Kirschner, P. (2006). Social and cognitive factors driving teamwork in collaborative learning environments: team learning beliefs and behaviors. Small Group Research, 37(5), 490-521.

Van Driel, J., Veal, W., \& Janssen, F. (2001). Pedagogical content knowledge: an integrative component within the knowledge base for teaching. Teaching and Teacher Education, 17(8), 979-986.

Van Driel, J., Verloop, N., \& De Vos, W. (1998). Developing science teachers' pedagogical content knowledge. . Journal of Research in Science Teaching, 35(6 ), 673-695.

Van Merriënboer, J., Kirschner, P., \& Kester, L. (2003). Taking the load off a learner's mind: Instructional design principles for complex learning. . Educational Psychologist 38 5-13.

Van Merriënboer, J., \& Paas, F. (2003). Poweful learning and the many faces of instructional design: toward a framework for the design of powerful learning environments. In E. De Corte, L. Verschaffel, N. Entwistle \& J. Van Merriënboer (Eds.), Powerful Learning Environments: Unravelling Basic Components and Dimensions (pp. 3-20). Amsterdam: Elsevier Science.

Veenman, M., Van Hout-Wolters, B., \& Afflerbach, P. (2006). Metacognition and learning: conceptual and methodological considerations. Metacognition and Learning, 1, 3-14.

Veenman, M., Wilhelm, P., \& Beishuizen, J. (2004). The relation between intellectual and metacognitive skills from a developmental perspective. Learning and Instruction, 14(1), 89109. 


\section{The psychological dimension of transformation in teacher learning}

Vermunt, J., \& Vermetten, Y. (2004). Patterns in student learning: relationships between learning strategies, conceptions of learning, and learning orientations. Educational Psychology Review, $16(4), 359-384$.

Webb, N., Franke, M., Ing, M., Chan, A., De, T., Freund, D., \& Battey, D. (2008). The role of teacher instructional practices in student collaboration. Contemporary Educational Psychology, 33, 360-381.

Wilson, N., \& Bai, H. (2010). The relationships and impact of teachers' metacognitive knowledge and pedagogical understandings of metacognition. Metacognition and Learning, 5, 269-288.

Wilson, N., \& Smetana, L. (2011). Questioning as thinking: a metacognitive framework to improve comprehension of expository text. Literacy, 45(2), 84-90.

Wilson, S., Shulman, L., \& Richert, E. (1987). "150 different ways"' of knowing: Representations of knowledge in teaching In J. Calderhead (Ed.), Exploring Teachers' Thinking (pp. 104-124). New York: Taylor and Francis.

Zembylas, M. (2007). Emotional ecology: the intersection of emotional knowledge and pedagogical content knowledge in teaching. Teaching and Teacher Education 23, 355-367.

Zohar, A., \& Ben David, A. (2008). Explicit teaching of meta-strategic knowledge in authentic classroom situations Metacognition and Learning, 3, 59-82. 